\title{
Disabling God in an able world? Analysis of a South African sermon ${ }^{1}$
}

\begin{abstract}
In this article the Heidelberg Method of sermon analysis is used to analyse a sermon preached in South Africa one month after the first general democratic elections, held in April 1994. The fundamental hermeneutic structure of the sermon is revealed to consist of three parts: a historical view of God's acts in the past; a particular understanding of God's intent and possible actions in the future; and an activist imperative that seeks to collapse and condense past and future in the present. The basic question that is posed concerns the God-image in the sermon: how is God pictured, if at all? And: how is this related to experiences of fragmentation in (postapartheid) South Africa?
\end{abstract}

\section{SOUTH AFRICA: THE END OF LEGALISED FRAGMENTATION?}

Apartheid could be described as legalised fragmentation, i.e. legalised isolation and enforced exclusion of designated groups. For centuries, from the times of colonialism, South Africans were kept apart in various ways - and in the time of legalised apartheid they were also separated in a geographical fragmentation of the country, with the fragments euphemistically called "homelands". South African citizens were separated and society fragmented not only on beaches, train stations, public amenities, work places (so-called "petty apartheid"), but more importantly also in the spheres of political power and economic affluence ("grand apartheid").

The release of Nelson Mandela, ${ }^{2}$ leading to the first democratic general elections on 27 April 1994, was described by many as "nothing short of a miracle". This dramatic event was hailed across the globe and scenes of seemingly unending queues of people waiting their turn to vote - the majority of them for the first time in their life - were splashed onto television screens for millions to witness. It seemed like the end of legalised fragmentation: the dawn of a new era of unity, reconciliation and connectedness. ${ }^{3}$ South Africa once again became part of the international community, experiencing the fruits of the video-sphere with its technological networking by means of the internet, television, cell phones etc. - so that one could say that, at least on a technological level, we were no longer fragmented, but rather enabled to become part of the connected globe (cf. Debray 2000: 166). ${ }^{4}$

\footnotetext{
1 Paper delivered at the $9^{\text {th }}$ International Conference of the Societas Homiletica, held in New Haven, Connecticut, USA, 1-5 August 2010. The theme of the conference was: Picturing God in a fragmented World.

2 Time and space constraints do not allow me to describe the momentous events leading up to this breakthrough in detail. For an overview of this period, cf. Gilliomee and Mbenga 2007: 330ff.

3 This is perhaps best epitomised by the events of the Rugby World Cup in 1995 (when South Africa was crowned as the world champion) and more recently the Soccer World Cup (June 2010), being hosted by South Africa.

4 Television, for instance, was withheld from South Africans until as late as 1973.
} 
Obviously, this fundamental reconfiguration (or defragmentation) of our society also found its way into countless theological debates and analyses, before and after the elections. It was articulated in thousands of sermons, South Africa being a religious ${ }^{5}$ country with a myriad of churches.

As an example of these homiletic reflections I chose a sermon that was delivered in a radio broadcast by a Presbyterian minister ${ }^{6}$ from a middle-class suburb near Cape Town on 29 May 1994 - about a month after the April general elections. It grapples with a profound theological question, namely how to picture God in a fragmented world, here with the added dimension that this sermon was preached in the immediate aftermath of one of the world's major political attempts to create unity within a country renowned for its fragmentation. This article is written sixteen years after the sermon was preached and obviously certain things have changed in the process of rebuilding our country and reconnecting to the international community. On the other hand, it could be argued that many of the issues of apartheid are still with us, haunting us, and might even have intensified. Sixteen years later we are still fragmented in some regards, with people such as the ANC Youth Leader Julius Malema singing "Kill the farmer, kill the Boer", and white extremists re-organising for possible civil war. On the one hand, we are connected South Africans carry more cell phones per person than those in any other African country! - and yet, on the other hand, we still seem to be disconnected in many ways. The question is: did sermons like this one help us in our time of transition? Did they launch us on a path of healing, or the contrary?

In what follows I offer an in-depth analysis of the sermon, utilising the Heidelberg Method. ${ }^{7}$

5 According to the Pew Forum on Religion and Public Life, published in Washington in April 2010, 89\% of South Africans are Christians. The complete report can be viewed at www.pewforum.org.

6 For the sake of anonymity, the name of the preacher is omitted.

7 The constitution of the Societas Homiletica states that sermon analyses, done in collaboration with international colleagues, should always be part of the agenda of the Societas. I offer this analysis in remembrance and in honour of Rudolf Bohren, who passed away on 1 February 2010. Bohren was my Swiss mentor, my Doktorvater, to whom I am indebted for many things, also fundamental theological formation. Briefly put, the Heidelberg Method could be described as follows: the method originated from research done by homiletical study groups at the Practical Theological Seminary of the Karl Rupprecht University of Heidelberg, Germany, during the late 1970s. After the theoretical basis had been formulated, it was published for the first time at an international symposium on preaching held in Heidelberg on 8-12 October 1986. Here the Swiss practical theologian Rudolf Bohren, the German author Gerd Debus, and others shared their experiences in applying this method with a broader homiletical community. Generally speaking it can be called an intra-textual approach, which intends, by means of a "close reading" of sermons, and by implementing rhetorical and theological criteria, to interpret the Word of God in, and often against, the preached Word. Simply put, it asks: to what extent does the preached Word articulate the Word of God? Or in the definition of Bullinger: is the preached Word of God indeed the Word of God (preadicatio dei est verbum dei)? As an analytical method it naturally represents a framework of interpretation. Its intention is therefore not to be the final word on specific sermons, but rather to open up a dialogue concerning these sermons. It wishes to serve the maturing of preacher and congregation, the latter to its full stature as complete church (ecclesia completa), a church that has both the ability and right to judge the preached Word (Luther). It therefore literally takes preachers at their word(s), trying to truly understand them, sometimes even up to the point of understanding them better than they understood themselves; trying to grasp the pivotal, and often subconscious hermeneutical decisions which underlie their sermons. In doing this, the most basic questions are asked, such as: How is the biblical text implemented in the sermon? What congregation is presupposed and/or invoked? What role does the preacher play? And, of specific importance for this paper: What (kind of) God is pictured in the sermon? (cf. Bohren/ Jörns 1989: 55-61). There are of course also other methods of sermon analysis, for instance the Heidelberg model with the use of the Kwalitan computer program; the hermeneutical model developed by Vaessen; the model for researching the sermon as a Word of God by Stark; the combination 
This method aims, inter alia, to disclose the fundamental hermeneutic structures of sermons. In the following analysis I will focus ${ }^{8}$ on this, while also venturing a theological interpretation.

\section{ANALYSIS}

\subsection{The God of the past}

At first glance the sermon ${ }^{9}$ looks inspiring and comforting (i.e. theologically "correct"), indeed like a word fitting the times. However, deeper analysis of the fundamental hermeneutic structure reveals that there is more going on beneath the surface than meets the eye. The sermon takes as its text Joshua 3:1-17, which depicts Israel in transit, on the point of crossing the river Jordan, and then uses it to draw a parallel with a South Africa that faces an uncertain future, wherein property, political power, security of jobs and businesses are threatened (69-71). Against the backdrop of these uncertain times, the congregation is called upon to trust God $(66,90,106)$, to acknowledge and accept God (34-36) since they need - as was the case with Israel facing the Jordan - God's divine intervention (142-143).

The sermon is characterised by two tensions, the first obvious and on the surface, so to speak, the second somewhat hidden, but nonetheless dramatic and essential for the understanding of the hermeneutical structure of the sermon. The first tension flows from the preacher's assessment of the South African transition. Looking back at the election of April 1994, i.e. historically speaking, the preacher can describe what has happened as nothing short of a miracle (18). None other than God has delivered us from oppression and exploitation $(31-32 ; 46)$. Looking to the future, however, the preacher speaks for people who are nervous and uncertain, en route to an unsafe, unknown destination (68-69). For them the transition is painful and difficult (72), not without dissatisfaction with the way things are going on in this country (137-138). While the past provides much reason for gratitude, the future constitutes an impossible destiny (31; cf. 62).

The second tension in a sense runs parallel to the first. Looking back at the great deeds of God with regards to Israel (again: historically speaking), as they are proclaimed in the biblical text, the preacher can stress the initiative of God resulting in the faith of Israel. God said it and they believed it to be true (1-2). That is the order, the (theological) sequence of events. Quoting from Hebrews and Joshua, the preacher underlines the miraculous working power of God amongst the people of Israel (13-14), how God cares... rescues... sets them on a new path (14-16). What God has done (in the recent past) in South Africa is cited as yet another example of this miraculous initiative of God - so much so that the order: God acts and people respond, is now reduced to God's initiative alone: We may have stopped believing and trusting in God in the measure of those people of Biblical times, but God is still very much present and very much alive today in the world (20-22). This is indeed the preacher's basic intention in his sermon: to elevate the faith of his listeners to the measure of those people of biblical times, to transform them into champions of faith (cf. 102-103). One could say: he intends to empower and enable them to achieve the level of faith of these biblical examples.

of the Heidelberg model and Stark's model by De Klerk, De Wet and Letsosa; and the grounded theory model for inductive analysis of sermons in order to develop a theory from the data. For an overview of these approaches cf. Pieterse 2009:1.

8 This implies that not every sentence and/or word of the sermon is necessarily reflected in the analysis. Obviously the preacher also says some moving and noteworthy things, but insofar as they do not impact on the basic hermeneutic structure, they are not mentioned or analysed.

9 The complete sermon is attached as addendum. It represents a verbatim reproduction of the sermon as it was preached. It has been numbered in the left column for easy referencing. Direct quotations are done in bold. 


\subsection{The God of the future}

In order to achieve this, he asks four questions, taken from the example of Jordan, and once again he confirms the sequence: How a people among whom God works are moved and prompted to respond in faith (28-29). It is interesting to note that the first three of these four questions (where, how, when and why God works; 27-28) are all answered in an indicative fashion, ending in a personal note in the present tense, for example: Jesus is with you. He is there... (41); Through the Spirit God is at work in your life right now, right this minute (46-47); The same is of course true for you and me today (55). But then comes a telling switch: the last question does not end in the present, indicative tense, but as a future possibility: He wants to encourage faith in us so that we might trust Him. He wants us to embrace his Lordship (57-58). Now we hear of God's intent (57).

Why this sudden change in tense? A possibility might be that the preacher wants to prepare the listener for the second part of his sermon in which he "applies" what he has said so far to people living in uncertain times and facing an uncertain future. Therefore the break and contrast effected by "But", as he states: But what does the Jordan story have to say to us this morning? (59) "But" forms the bridge between God's deeds and God's intent, signalling the tension between what God has done and what God wants to do in South Africa in a time of transition.

The second part of the sermon indeed slants towards the future, stressing possibilities. This is expressed grammatically in a flood of future tenses. A few prominent examples: God can take the worst and turn it into his very best. God can take your impossibilities and turn them into probabilities. He wants to do that for you, right here, right now (86-88); He can and will see you through... (131); God will be your strength and refuge (138-139), etc. Perhaps the best example of this tension between salvation history and salvation possibility is seen in 96-100. Looking at the biblical text, the preacher states: Friends, Joshua was not afraid because God went before him... Addressing the congregation, he says: How are you crossing your Jordan today? Is it alone? Is it on your own strength? God wants to go before you. God wants to lead you. God wants to help you. One could say, with due respect, that God is put on hold. God wants to act, but apparently does not. Why? Something has to happen first; certain conditions must first be met. But what are they?

\subsection{Homo intactus: the human of the hour}

The listener must first act. Between God's acts in the past and God's acts in the future stand the acts of the congregation in the present. Therefore it is quite logical that the preacher continues and starts the third part of his sermon with: The Jordan story tells us what we must do (116). Now the emphasis no longer falls on what God has done according to the Jordan story, but what we must do. Indeed, while the present indicative dominates the first part of the sermon, and the future tense the second, the imperative now structures the third. The preacher repeatedly says: you must... we must... we must... you must (cf.121, 125, 128, etc.).

If I am not mistaken, and this is said not lightly, the preacher falls prey to a fatal trap of religious activism, ${ }^{10}$ born out of an inappropriate God-image. I believe that he does not do this deliberately. His bona fides should not be questioned; in fact, as preachers we probably do not have the conscious and deliberate intention to proclaim lies (Augustine: mendacium

10 This could also be called moralism, but in my opinion this classic concept has been contaminated to such an extent that it needs revisiting. Postmodern people, for instance, often equate (a call for) moral values with moralism, which is of course not the case. The notion of religious activism is current, often used in debates of inter-religious nature. A case in point would be the vehement reaction, and indeed activism, of Muslim people recently in South Africa against a satirical depiction of Mohammed by the renowned cartoonist Zapiro. The debate spilled over into Parliament and almost also into the courts. 
est enunciato cum voluntate falsum enuntiandi; cf. Cilliers 2006:2). We should have sympathy with the preacher. The difficulties in crossing the "Jordan in South Africa", here and now (cf. 7172), the pressures of the present, ${ }^{11}$ cause the preacher to interpret, albeit subconsciously, this present as a vacuum between God's deeds and God's probabilities (87), a vacuum into which steps none other than the religious human being, (homo religious), who is also an intact human being (homo intactus). This human being must now salvage the precarious state of affairs. Through his and her choices (cf. 147-148) the future - that which God wants to do - will indeed be like the past - that which God has done. This intact, religious human being must ensure that past and future coincide in the present. In effect God's acts hinge on what the listener "must" do in the present.

This is stereotypical of religious activism, stating what God has done and what God will do, but more importantly: what people must do to activate God's deeds now (cf. Josuttis 1966:24). In principle, or at least linguistically, it leaves the present devoid of God's acts. Ironically the preacher goes to great lengths to stress the fact that God and Jesus never change, that they are unchanging (26). But the preacher's dogmatic confession about God is short-circuited here by his homiletical methodology. God in fact does change, or rather: is changed by the sermon from present and active to absent and inactive. This image of the absent and inactive God is underlined by the stereotypical structure of religious activism (cf. Cilliers 1996:98), which could be described in a nutshell as follows:

1. God did (in the past)

2. God wants to (in the future)

3. We must (in the present).

\subsection{Disabling God in an able world?}

But, one could ask, is God not present? Of course God's presence should not be understood in a mechanical or deterministic way. God's presence is always an elusive presence; God's revelation is always also an act of concealing (Terrien 1978: 321, 470). God is, simultaneously, a deus revelatus and a deus absconditus. God is often revealed in paradoxes - even as One wearing masks. According to Luther, every part of creation in fact forms part of God's masquerade (Ideo universa creatura eius est larva dei; W.A. 40:1:174; 17: II: 192). But this is not what is at stake here. In sermons like these, God is taken out of the picture by human beings. God suffers subordination according to the conditions of human beings, suffers anthroponome subordination (cf. Landau 1981:191). The actions and abilities of human beings, which are ironically intended to activate God, in fact disable God. Religious activism could in this case be called the act of disabling God by means of religious rhetoric. The preacher is so influenced by the paradigm of (or in this case: the longing for) an empowered and enabled ${ }^{12}$ post-apartheid South Africa that the fundamental hermeneutical structure of his sermon disables God. The religious activism of the homo intactus results in the depiction of an incapacitated and disabled God. Again: this is not said lightly. On the contrary.

The way in which the preacher steps into the activist trap of disabling God by means of religious rhetoric is nowhere better seen than in 127-135. The preacher prepares the listener for what is to come by first asking a little more of the congregation (127; euphemistically?), and

11 As experienced 16 years ago. Cf. the previous discussion on page 2.

12 The notion of an able world comes into play here: in a consumerist and market-driven society weakness and failure and lament have no place. Success is the key word. Arbuckle finds this mentality a sad state of affairs and contends that "This is a thoroughly pathetic and frightening picture of a death-denying culture, for just as we seek to deny physical death, so also we are apt to ignore all kinds of painful personal and social loss. We have developed a pervasive mythology in which success is the hallmark of Western identity and failure or loss has no place in it" (1991:44). 
then quoting Joshua 3:5 to substantiate this. In the process the quoted text is twisted ever so slightly, given a seemingly innocent but altered nuance, with far-reaching results. The preacher states: You must consecrate yourself to God... What happens when you consecrate yourself to God? The Lord will do amazing things among you. So you see, my friends, when you commit your life to God that's precisely what you will see (127-135).

The biblical text of course does not say this. Although the text does speak about consecration to God, as the first part of the preacher's statement articulates, it is the second part of his statement that derails the intention of the text. Joshua 3:5 says: "Purify yourselves, because tomorrow the Lord will perform miracles among you" (GNB). In his eagerness to fill what he senses as a vacuum between past and future, the preacher changes the preconditioned action of Israel into a conditional action, which must be duplicated by his hearers. A homiletic slip takes place between the cup of the text and the lip of the preacher, with devastating effects. God's action now depends on whether we can purify ourselves most completely $(128,129)$. Because $e^{13}$ now becomes when. Theological grounding is changed into activist temporality; God's initiative is transformed into human timing. ${ }^{14}$

Of significance here is the use of the superlative. Extensive sermon analytical studies have shown that superlatives and tautologies are often characteristic speech-patterns of religious activism (cf. Josuttis 1966:20ff.). The implication is disheartening (not comforting, as the sermon suggests at first glance; cf. 2.1). It could even be called cruel: must we consecrate ourselves most completely - before God can act? No! It could even be called a form of sermonic pathology: to manipulate (activate) people to activate (manipulate) God, i.e. to utilise an inappropriate Godimage in order to address, but also manipulate the needs of people. No!

\subsection{Rhetorical camouflage?}

One could of course argue that the preacher merely strives to balance the first part of the sermon with the latter, to complement the indicative with the imperative (analogously to what Paul does in some of his letters). I do not believe that this is the case. The first part of the sermon rather

13 The Hebrew word for because, $k \hat{\imath}$, is a particle which means: because, for, when. It denotes reason, in this case because of the acts of the Lord. The temporal possibility (when) is also linked to the active subject, the Lord.

14 The analogical schematism that is used in this sermon (i.e. between Israel and the South African nation) in fact dispels unilaterally the tension that characterises the dialectic relation between God and time. God is revealed in history, and this is no deceptive revelation, but God's Being that is revealed to us; it is God who makes history in this revelation. Between God's Being and God's revelation, there is no tension. Yet God is also more than God's revelation. God's reality is not dissolved in God's work. Because God is more than God's works, God can work; because God is greater than God's revelation and precedes it, God's Being can be revealed (Durand 1976:47). Neither has God, in God's revelation, been given to us as manipulable in our hands. In the analogical schematism, however, God cannot be viewed as One who acts differently and surprisingly in the relative times. God rather becomes bound and thus idolised in the relative times. By implication, God is divided into two. On the one hand, God is written into an ancient situation (e.g. the time of Joshua). On the other hand, God becomes trapped in the present day. Strictly speaking, God cannot act freshly and differently. Ironically, by God being so trapped in history and in proclamation, God is taken from history and God's sovereignty over history is taken from God. If I interpret this correctly, through this, God becomes an unhistorical principle. Actually, this kind of analogical schematism is a way of escaping from time, from the continuation of time, and from God's self-revelation in time; it is a grasping back into history to avoid contemporary realities and the future. It represents a particular form of anti-prophecy that does not dare to jump ahead, but rather arrests time and reproduces history. In this arrest and reproduction, God becomes comparable and inactive; God is incapacitated and disabled (cf. Cilliers 2006: 20-23). 
serves to camouflage the last and indeed focal part, where the preacher now in fact does expect his listeners to elevate their faith to the measure of those people of Biblical times, as already hinted at in the introduction of the sermon (21). These biblical characters become examples that the listener must copy, and as such become a law unto themselves. They become non-human beings, and are in fact held forth as legends, as people who never failed to put their trust in God... never gave up on God $(3,5)$. Never? Really?

The description of Joshua in 90-94 gives fuel to the present-day homo intactus, enabling him/ her to be unshakeable (cf. 8). Joshua is pictured as anything but vulnerable, the perfect allegory for able believers, for people who have a (tautological) believing faith (94). He does everything absolutely right, never failing, never faltering. And the question following this, of course, is: Do you have such faith...? (94)

Jordan itself no longer stands as symbol of God's faithfulness, but becomes a paradigm for manipulation, based on the presupposition that there is an undisputed link and identification, i.e. a situational analogy between God's acts within the nation of Israel and the needs of various groups in South Africa today. As a matter of fact, the use of such an analogous scheme is symptomatic of a search for security in a time of emergency (cf. Cilliers 2006:15 ff.). The analogical use of the Jordan narrative serves to address the uncertainty and fear of present-day South Africans (89). But more importantly: the hinge on which this paradigm of manipulation turns is the imperative to act according to the unshakeable examples of Joshua and other biblical champions of faith. "Jordan" becomes a pious, inner state of strength that we can derive through duplication of these champions of faith - then we can face experiences like changing of jobs, buying new houses, entering into marriage, etc. (72-80) Then we are indeed able. In the process, The Ark of the Covenant of God, which represents the actual presence of God (119), becomes a symbol of power, of human enablement; God's presence is utilised for empowering and enabling. In short: the Ark becomes the elongation and ultimate legitimisation of a religious activist agenda.

In my opinion, the introductory passage of the sermon already harbours in itself, and in fact prepares the listener for, this activist end. In the very first sentences of the sermon we hear: The scriptures abound in examples of men and women who took God at his Word... Can the same be said about you and me this morning? $(1,6,7)$. This basic question, which forms part of the backbone of the sermon, is repeated in 94-95: Do you have such faith to believe that God will rescue you no matter what your situation? Rhetorical questions such as these are characteristic of classical religious activism (Josuttis 1966:20ff.). What answer does the preacher expect? Yes or no? Of course we do not "have" such faith! "Must" we now generate it? "Must" we now consecrate ourselves so "most completely" that we are able to see the Triune God as the preacher implores as elsewhere (125-126)?

It is ironic and inevitable: in the very beginning of the sermon already lies its manipulative end. In the last paragraph we hear of God's invitation which is still open (145-146), but this becomes subject to our invitation of Jesus into our lives (148). The question indeed is: who in fact invites whom? It would seem as if the whole sermon is geared towards this end, as a type of "altar call" to listeners over the radio: to admonish them to "invite Jesus into your lives".

God's miracle now only takes place as I entrust myself to thee (152). The sphere in which the sermon operates remains the inner state of the religious hearer; the hermeneutical space remains reduced to the pious inner circle of the homo religious and homo intactus. The same pious material is used again and again, and ultimately, all sermons like these end up with "an invitation to invite Jesus into your lives" - as if we are able to do that. This stereotypical pious encircling of biblical texts bypasses the reality outside the circle, in this case the reality of a South Africa in a time of transition. The hearers finds themselves in uncertain times, but they are not 
called to make decisions and act within this situation; they are rather taken out of this to a pious sphere where they must (for how many times still?) make a decision for God and to "invite Jesus into their lives."

In a sense, the first part of the sermon is sabotaged by the second and especially third part. All the glowing indicatives of the first part (where the preacher spoke historically about what God has done) are funnelled through, and coloured by, the God-image of the second part (where the preacher spoke about the future intent of God), and ultimately by the imperatives of the third part; for instance, God's choice to work amongst us (56) becomes subordinated to our choice to invite Jesus into our lives (148); the fact that God works in God's own time (52) is shackled by people's timing - when you consecrate yourself to God, most completely (128-129;132-133). As a matter of fact, the four questions of the introduction - where, how, when and why God works (27-28) - are all subjected to the way in which we "must" now cross our Jordan. God now indeed does work under force or pressure (cf. 48-49), namely that of the homo religious and homo intactus; God no longer is in control (cf.106), no longer holds the initiative, no longer acts as prima causa, no longer goes before us so that we may follow, but rather follows us as we go before God.

\subsection{Deus debilitatus?}

It is clear that the sermon contains many ironies. The preacher speaks about the unchanging God and yet his sermon changes (disables) God; he intends to picture what God will be doing (futurum), but does not understand that God is (continuously and actively) coming into the present (adventus); he calls upon his hearers to understand that God works in God's own time, and that we are often frustrated by what seems to be God's slowness in responding to our needs, even stressing that we have to wait like Moses and Joshua did, because the same is of course true for you and me today (53-55), and yet his religious activism does not allow him to wait. The God of the future (deus futurum) must be brought into the present through pious activities, instead of waiting for the revelation of the presence of the continuously coming God (deus adventus).

Perhaps the biggest irony of all is the fact that the preacher presents (pictures) the image of a disabled God in his sermon, not understanding that there is indeed another picture of the disabled God, a picture not created through the activism of the homo intactus, but through the revelation of God's incarnation and inhabitation. God's presence (the Ark of the Covenant in Joshua) is not "a mighty power" that blows everything and everybody away. God does not side with the mighty. ${ }^{15}$ God's indwelling power (or ability) is rather of a different order: it is that of a God crucified, resurrected and poured out on all flesh. Not within an able world, but within a disabled world, for the sake of this disabled world. In the process God is not left intact, but is shattered; God is not whole, but fragmented; God is not able, but disabled and incapacitated (deus debilitatus). ${ }^{16}$

In a moving account the theologian Nancy Eiesland, herself being a disabled person, speaks as follows of her epiphany in regard to the image of God:

I had waited for a mighty revelation of God. But my epiphany bore little resemblance to

15 One is reminded of President Zuma's recent claims that God is on the side of the ANC, being there since its conception, and that the ANC will rule until "Jesus comes again." We are reminded of the questions that we posed at the beginning of this article, namely: did sermons like these help us in our time of transition? Did they launch us on a path of healing, or the contrary? Dare we say that sermons like these contributed towards picturing a God that can be activated to "be on our side"? A God that can be "called in" to legitimise our search for power? And that ironically, through this, God is in fact incapacitated and "taken out of picture" in post-apartheid South Africa?

16 Debilitatus is the past participle of debilito - to debilitate, weaken, disable. 
the God I was expecting or the God of my dreams. I saw God in a sip-puff wheelchair, that is, the chair used mostly by quadriplegics enabling them to manoeuvre by blowing and sucking on a straw like device. Not an omnipotent, self-sufficient God, but neither a pitiable, suffering servant. In this moment, I beheld God as a survivor, unpitying and forthright. (1994: 89)

God is on the side of, with and within, suffering (disabled) humanity. The preacher, as a South African, should have known this.

\section{BIBLIOGRAPHY}

Arbuckle, GA 1991. Grieving for change. A spirituality for refounding communities. Strand, London: Cassel Publishers Limited.

Bohren, R; Jörns, KP 1989. Die Predigtanalyse als Weg zur Predigt. Tübingen: Francke Verlag. Cilliers, JH 1996. Die Uitwissing van God op die kansel. Ontstellende bevindinge oor Suid-Afrikaanse prediking. Kaapstad: Lux Verbi.

Cilliers, JH. 2006. God for Us? An analysis and assessment of Dutch Reformed preaching during the Apartheid years. Stellenbosch: Sun Press.

Debray, R 2000. Introduction à la médiologie. Paris: Presses Universitaires de France.

Durand, JJF 1976. Die Lewende God. Pretoria: NG Kerkboekhandel.

Eiesland, NL 1994. The Disabled God. Towards a Liberatory Theology of Disability. Nashville: Abingdon Press.

Gilliomee, H; Mbenga, B 2007. New History of South Africa. Kaapstad: Tafelberg.

Josuttis, M 1966. Gesetzlichkeit in der Predigt der Gegenwart. München: Kaiser Verlag.

Landau, R 1981. “Komm, Heiliger Geist, du Tröster wert..." Gestaltungen des Heiligen Geistes. Ev Th 41/3 Jahrgang, 187-211

Luther, Martin. 1883. Weimarer Ausgabe (WA). Weimar: Hermann Böhlau.

Pieterse, HJC 2010. Die Keuse van 'n model vir inhoudsanalise van preke oor armoede en aan armes as hoorders. In die Skriflig. Vol 44 No 2, 1-16.

Terrien, S 1978. The Elusive Presence. Toward a New Biblical Theology. San Francisco: Harper and Row.

\section{ADDENDUM}

\section{CROSSING THE JORDAN}

SOUTH AFRICA, MAY 1994

The Scriptures abound in examples of men and women who took God at his Word. God said it and they believed it to be true. In spite of the context, the conditions and circumstances they never failed to put their trust in God. Now let us not for any moment believe that they had it easy. In fact, they suffered more than we can possibly imagine but they never gave up on God. Why? Because they knew God, they knew that they could trust Him; they knew that they could depend on Him. Can the same be said about you and me this morning? That no matter what we are going through in this life right now we will not be shaken or uprooted from our position in God? But like the psalmist in Psalm 46 we will find our refuge and strength in God our Creator?

The writer to the Hebrews in chapter 11 commends people like Abraham, Noah, Moses and Enoch as the champions of faith, as those, who in spite of their adversities, surrendered to God in hope. In fact, for most of them, their situation was indeed of nothing less than a miracle. The Jordan story we read this morning is another example of the miraculous working power of God amongst the people of Israel. It is a story of how God cares for his people, of how God rescues them out of bondage and of how God sets them on a new path of discovery and hope.

Perhaps we as South Africans can understand that today. For many in our country the present transition is nothing short of a miracle. Who would have believed that in 1994 we would have 
seen changes that we are now witnessing in this country, in our government as a whole? Indeed, the days of miracles are not yet over. We may have stopped believing and trusting in God in the measure of those people of Biblical times but God is still very much present and very much alive today in the world. The world may be modern and our perceptions of God may be changing with the modern world but the good news is that God is still the same - yesterday, today, and forever. Though it may change, but Jesus - never!

The Jordan story is one example of the miraculous activity of an unchanging God. It suffices to tell us where God works, how God works, when God works and why God works. But more importantly, it serves to tell us how a people among whom God works are moved and prompted to respond in faith.

Getting back to the Jordan story then, we find the people engaged in a determined but in a somewhat impossible destiny. They wanted to break free from a land of oppression and exploitation and enter into the Promised Land where they could establish a city of God. But they realized that they could not do this on their own human strength. They needed God's divine intervention. Perhaps this answers the question on where God works. He works wherever there is a need, especially wherever there is a need for Him to be recognized, accepted, and appreciated as God. He's always at work, bringing people to faith and transformation. The gospel writer Matthew tells us in chapter 8 that Jesus is always there in the middle of the storm and what is the purpose of Him being there? To bring peace and calm. Maybe you have a serious need right now; maybe you are experiencing a storm in your life right now. My plea to you this morning is this: do be assured that Jesus is with you. He is there, restoring peace and calm in your broken life.

Let's tackle the second question: How does God work? The Bible tells us that He works in a variety of ways. The Elijah story tells us that God works in a whisper. The psalmist tells us that God works in a thunderstorm or in an earthquake. But the Jordan story this morning tells us that God stills the waters, divides the seas and breaks down the walls of oppression of whatever kind. Through the Spirit God is at work in your life right now, right this minute.

That brings us to our next question: When does God work? The Bible tells us that God does not work under force or pressure. On many occasions Jesus is compelled by the crowd to show signs bearing testimony to his claim that $\mathrm{He}$ is the Son of God. But in each given moment Jesus refuses to do so. There is one fact that Jesus establishes in all of this and that is that God works in his time. Sometimes we have to painfully discover that for ourselves. Our desire to get quick answers is often frustrated by what seems to be God's slowness in responding to our needs. Moses and Joshua can ask of God but they must trust Him, and wait. The same is of course true for you and me today.

Let's then look at the last question: Why does God choose to work amongst us? The Bible tells us that it is his intent on reconciling us unto Himself. He wants to encourage faith in us so that we might trust Him. He wants us to embrace his Lordship.

But what does the Jordan story have to say to us this morning? Friends, I believe that each of us, whether we know it or not, whether we admit it or not, whether we have seen it or not, have a Jordan to cross. The Jordan I am talking about is the pain, suffering, and hurts of life. Jordan represents the impossibilities. Jordan represents those moments in which we need divine intervention. Jordan refers to the situations which require nothing less than a miracle. In the words of CS Lewis: Jordan refers to those moments when we say: "Lord, there's nothing I can do. I'm depending on You." Jordan is not necessarily "giving up" in as much as it is "giving over". It's taking God at his Word. It's trusting God for the future. Jordan means crossing the frontiers of the known into the borders of the unknown.

Perhaps that is exactly what we are doing in our country right now. Many people are very 
anxious and nervous about the New South Africa. They are afraid of the unknown. We are not certain about so many things - about the security of our jobs, about our properties and businesses. We are afraid of losing our power, influence and privileges as a people. Yes, we are crossing the Jordan and it is painful and difficult. There are many of us who are crossing from the known into the unknown zone in life. Perhaps you want to change your job but you are not certain of whether you are doing the right thing. Maybe you want to buy a new house but you are not sure whether you can afford it in the long term. Maybe you want to enter into a marriage but you are not sure if that's what you really want in life. Maybe you want to reconcile a marriage that is already broken but you are not sure whether it is going to work out again. You want to change your lifestyle but you are not sure whether you will survive the changes. You want to improve the home situation but you don't know if it's going to work out in the end. Yes, we cross the Jordan of uncertainty almost every day of our lives, don't we? In fact, many of us are probably already saying "It's going to take nothing less than a miracle to save my marriage, my business, my family, my home, my house, and my life." But friends, let me assure you this morning that God is in the business of miracles. You thought that dividing the sea was scientifically impossible, right? Wrong! It's possible with God. God is the God of all impossibilities. God can take the worst and turn it into his very best. God can take your impossibilities and turn them into probabilities. He wants to do that for you, right here, right now.

Jordan, then, does not represent uncertainty and fear. Instead it stands for hope and faith. Joshua trusted God. When God told him "I will take you and my people with you across the waters of the Jordan" Joshua did not stop to ask if that was scientifically possible. He knew his God. He trusted in his God. And so it is that Scripture tells us that no sooner they touched the water's edge, the waters divided. The faith that Joshua expressed and exercised was not a foolish faith but a believing faith. Do you have such faith to believe that God will rescue you no matter what your situation? That God will save your home, your marriage, your business, your job and our country? Friends, Joshua was not afraid because God went before him. In verse 14 of chapter 3 we read that the Ark of the Covenant of the Lord went ahead. How are you crossing your Jordan today? Is it alone; is it on your own strength? God wants to go before you. God wants to lead you. God wants to help you.

Psalm 27 says "The lord is my light and my salvation; I will fear no one. The Lord protects me from all danger; I will not be afraid." God wants us, like the champions of faith, to be sure of what you hope for and certain of what you do not see. The gospel writer Matthew tells us the same in chapter 6:25 following. He says that we should not be worried about what we will eat, what we will wear, what we will drink. Instead we should put our trust in God and He will see us through. Why? Because God is in control.

A joke is told about a man who fell down a cliff. Fortunately for him, he managed to grab onto a branch of a small tree. He couldn't move or do anything to save himself from falling further to the bottom. So he looked up and prayed to God for help. Then a faint voice came: "Let go." The man looked up and again a voice said, much louder: "Let go." The man looked up, he looked down again and he looked up again and then he shouted at the top of his voice: "Is there anybody else up there?" Friends, crossing the Jordan means letting go and allowing God to take over. But faith in God does not mean resigning. Instead it means reassigning. Not looking to one self any more but depending on God, assigning the task to God.

The Jordan story tells us what we must do. So right now you are in life's deep end and you are asking: "What must I do to cross this Jordan?" Let's see what God says to Joshua and his people. In verse 3 of chapter 3 the leader said to the people: "When you see the Ark of the Covenant of God you are to move out from your positions and follow it." You see, my friends, the Ark represented the actual presence of God. So what they were really saying is this: "You must 
follow God." Friends, this is my advice to you as you cross your Jordan this day. Move out of your positions of depression, hopelessness, security, fear, discomfort, and sadness and follow God. Trust God. Very often people with problems get preoccupied with themselves. They narrow and limit everything to their depressing circumstances. When crossing the Jordan we must learn to see beyond ourselves. We must see the Triune God.

But following God involves a little more. In verse 5 the leaders said to the people: "You must consecrate yourself to God" meaning that they must give themselves to God most completely. Friends, as you cross your Jordan I implore you to do the same, to embrace the Lordship of Jesus Christ, you give yourself to Him most completely, to know for sure that He can and will see you through, to know that He is powerful and most able to carry you through the rough seas of life's experiences. What happens when you consecrate yourself to God? In verse 5, continued, we read: "The Lord will do amazing things among you." So you see, friends, when you commit your life to God that's precisely what you will see. Things may not necessarily change for you, you may still struggle to pay the bond, you may still suffer the loss of a loved one, you may still suffer with the sickness of alcoholism, your marriage may still end in divorce, you may still not be satisfied with the way things are going on in this country, but in all that you will not be alone. God will be your strength and refuge, your ever present help in trouble. And therefore you will not fear, though the earth gives way. You will say with the prophet Habakkuk: "I will rejoice in the Lord of my salvation."

Friends, you cannot cross your Jordans alone. Not on your own strength. You need divine intervention. You need God to put you on a new path of discovery, recovery and hope. Perhaps that's what you need right now. Maybe you have forgotten God. Maybe you have given up on God. Maybe you don't know God. As you cross your Jordan God's invitation is still open to you right this very minute. He says: "Call unto me and I will answer thee. Come to me and I will in no way cast you away." I trust that's what you will choose to do - to invite Jesus into your life. If you should desire that right now, why not say this prayer with me. Let us pray:

Lord Jesus, I invite you into my life. I know that I cannot cross my Jordan alone. I confess my need for your divine presence. Father, Son and Holy Spirit, work your miracle in my life right now as I entrust myself to thee.

Amen. 